

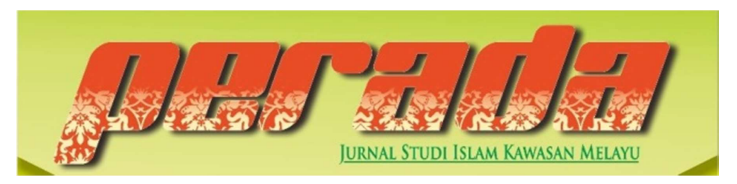

\author{
Perada: Jurnal Studi Islam Kawasan Melayu \\ ISSN 2656-7202 (P) ISSN 2655-6626 (O) \\ Volume 3 Nomor 1, Januari-Juni 2020 \\ DOI: https://doi.org/10.35961/perada.v3i1.69
}

\title{
PEMETAAN KONFLIK SOSIAL DAN PAHAM RADIKAL SEBAGAI SUATU KENISCAYAN DI BATAM PROPINSI KEPULAUAN
}

\author{
Pauzi \\ STAIN Sultan Abdurrahman Kepulauan Riau \\ pauzi@stainkepri.ac.id \\ Khairuddin Said \\ STAIN Sultan Abdurrahman Kepulauan Riau \\ said@stainkepri.ac.id
}

\begin{abstract}
ABSTRAK
Fokus kajian artikel ini hendak mengetahui tentang peta potensi konflik dan aksi radikalisme di Batam, Kepulauan Riau. Sebagai daerah multikultural dengan beragam golongan, banyak perbedaa yang dimiliki setiap masyarakat Batam. Dengan pembangunannya cukup pesat, Batam telah menjadi magnet bagi kehadiran pendatang untuk turut menjadi bagian dari dinamika pembangunannya. Konsep pembangunan yang memiliki daya dukung yang tinggi ditandai dengan daya dukung lingkungan sosial yang kondusif, benih-benih konflik dan perbedaan faham yang menjurus kepada radikalisme di hampir semua daerah bukan suatu keniscayaan. Dari penelitian yang telah dilakukan, maka diketahui beberapa jenis potensi konflik yang bisa memicu tindak kekerasan, seperti konflik sosial, konflik lingkungan dan agraria, konflik agama. Pontensi konflik yang tertinggi berkemungkinan terjadi di kecamatan Batam Kota, Bengkong, Batuampar, Sekupang dan Galang. Secara umum dapat disimpulkan bahwa konflik sosial dan radikalisme belum menunjukkan permasalahan dan tanda-tanda radikal sedangkan. Namun, untuk konflik agama perlu keseriusan dalam penanganannya terutama dalam hal pendirian rumah ibadah.
\end{abstract}

Abstract: The focus of this article's study is to find out about the map of potential conflicts and acts of radicalism in Batam, Riau Islands. As a multicultural area with various groups, there are many differences that each Batam community has. With its quite rapid development, Batam has become a magnet for the presence of migrants to be part of the dynamics of its development. The concept of development that has a high carrying capacity is characterized by the carrying capacity of a conducive social environment, the seeds of conflict and differences in understanding that lead to radicalism in almost all regions is not a necessity. From the research that has been done, it is known that there are several types of potential conflicts that can trigger acts of violence, such as social conflicts, environmental and agrarian conflicts, religious 
conflicts. The highest conflict potential is likely to occur in the sub-districts of Batam Kota, Bengkong, Batuampar, Sekupang and Galang. In general, it can be concluded that social conflict and radicalism have not shown radical problems and signs. However, religious conflicts need to be serious in their handling, especially in terms of the construction of places of worship.

Kata Kunci : Mapping, social conflict and radicalism 


\section{PENDAHULUAN}

Pembangunan yang dilaksanakan dewasa ini disamping memberikan dampak sisi positif juga memberikan dampak sisi negatif. Untuk itu masalah yang paling mendasar dalam pembangunan tidak hanya pertumbuhan akan tetapi terjadinya trans-pormasi pembangunan itu sendiri. Dari tranpormasi pembangunan akan memberi-kan pertama masalah keadilan sehingga semua orang dapat bekerja dan hidup layak tanpa adanya gejolak dan ganguan sosial serta tekanan dari pihak manapun juga, kedua kesinambungan sumber daya alam dimana setiap generasi harus memelihara sumberdaya alam dan lingkungan untuk generasi mendatang dan, ketiga partisipasi yaitu keikut sertaan semua pihak dalam pembangunan mulai dari input, proses dan output. Dengan disentuhnya permasalahan di atas, maka pembangunan merupakan gerakan rakyat dan hanya dengan begitu pembangunan akan berdaya guna dan berhasil guna sebagai suatu daya dukung.

Pembangunan daerah sebagai bagian integral dari pembangunan nasional diarah-kan untuk mengembangkan dan menyerasi-kan laju pertumbuhan daerah, antar kota dan desa, antar sektor serta antar daerah. ${ }^{1}$ Ideal-nya menempatkan manusia baik sebagai subyek maupun objek pembangunan adalah penting dan memandang lingkungan sosial sebagai suatu daya dukung untuk mewujudkan pembangunan berkelanjutan. Pembangunan yang berkelanjutan yaitu pembangunan yang memenuhi kebutuhan hidup masyarakat sekarang tanpa mengurangi generasi yang akan datang dalam memenuhi kebutuhan hidupnya. ${ }^{2}$

1 Ginandjar Kartasasmita, Pembangunan Untuk Rakyat: Memadukan Pertumbuhan Dan Pemerataan (Cides, 1996), p. 335.

2 Otto Soemarwoto, Ekologi, Lingkungan Hidup Dan Pembangunan Edisi Revisi (Jakarta: Penerbit Djambatan, 1997), p. 162.
Dari kedua konsep di atas jelas faktor lingkungan sosial diperlukan untuk mendukung pembangunan yang berkelanjutan, yaitu a) terpeliharanya ekologi yang esensial, b) tersedianya sumber daya alam yang cukup, dan c) tersedianya kondisi sosial ekonomi dan budaya yang kondusif. Konsep pembangunan yang memiliki daya dukung yang tinggi yang ditandai dengan daya dukung lingkungan sosial yang kondusif memberikan stimulus kearah yang lebih baik bagi kelangsungan kehidupan bermasyarkat dan bernegara walaupun benih-benih konflik dan radikalisme di hampir semua daerah bukan suatu kenistaan dan sesuatu yang mustahil, dengan kondisi lingkungan yang harmonis, kehidupan masyarakat yang senantiasa rukun dan damai yang diiringan perhatian pembangunan dari pemerintah konflik soaial dan radikalisme dapat diantisipasi sedini mungkin.

Pembangunan daerah sebagai bagian integral dari pembangunan nasional akan mendapatkan berbagai tantangan baru dalam proses globalisasi dewasa ini kondisi ini akan merupakan tantangan tersendiri bagi Provinsi Kepulauan Riau yang berhadapan langsung dengan negaranegara tetangga. Letak Wilayah Provinsi Kepulauan Riau terletak antara 0o29' Lintang Selatan dan 04o40' Lintang Utara serta antara 103o22' Bujur Timur sampai dengan 109o4' Bujur Timur. Provinsi Kepulauan Riau merupakan salah satu provinsi bahari di Republik Indonesia. Provinsi Kepulauan Riau dikelilingi laut dan daratannya terdiri dari banyak gugusan pulau. Berdasarkan hasil identifikasi Bakosurtanal, tercatat 394 pulau berpenghuni sedangkan 1.401 lainnya belum berpenghuni.

Seiring dengan itu, masalah keamanan dan ketertiban umum (social order) juga dihadapkan pada tatangan tersendiri pada era reformasi dan demokratisasi yang kini tengah dihadapi di 
Provinsi ini. Bidang pertahanan keamanan juga masih memerlukan tingkat sense of crisis yang tinggi serta menuntut sikap dan komitmen bersama yang kuat segenap komponen bangsa untuk mengelolanya. Masalah separatisme, jelas masih menjadi persoalan yang memerlukan perhatian yang serius.

Batam merupakan wilayah kepulauan yang ada di Provinsi Kepulauan Riau berbagai masalah konflik sosial seperti politik, ekonomi, budaya, perseteruan antar dan inter umat beragama, suku dan antar etnis, sengketa batas wilayah, sengketa sumber daya alam, serta distribusi sumber daya alam yang tidak seimbang dalam masyarakat adalah sebagian dari sekian banyak dari sumber konflik yang bisa mempengaruhi satu dan lainnya. Konflik-konflik yang terjadi juga tidak secara natural lahir dari unsur ketidak puasan masyarakat, akan tetapi ini dapat pula lahir dari pemicu-pemicu konflik yang harus dideteksi sedini mungkin agar tidak menjadi melebar serta memberikan dampak massive ke depannya serta radikalisme negatif yang membahayakan kehidupan bermasyarakat. Penyelesaian konflik-konflik dan faham radikalisme masih sangat perlu dipelihara momentumnya dan dilanjutkan dengan proses rekonsiliasi sosial yang sungguhsungguh antar berbagai kelompok yang terlibat dalam konflik sosial dan faham radikalisme terhadap perbedaan pandangan social, ekonomi, politik, golongan dan etnis serta perbedaan keyakinan agama.

Tidak dapat dipungkiri bahwa saat ini di Batam juga mengalami perubahan sosial budaya dan dinamika pembangunan yang sangat cepat. Gejala perubahan sosial budaya dengan kondisi keterbukaan yang terjadi tidak saja dalam artian positif (regressive), tapi juga dalam bentuk negative (degressive), seperti meningkatnya masalahmasalah sosial budaya dan radikalisme yang mengakibatkan rusaknya tatanan nilai-nilai sosial dan budaya.

Berdasarkan hasil pemetaan yang dilakukan bahwa trend konflik beskala kecil dan sporadis meningkat serta menyebar hampir di seluruh di seluruh wilayah Indonesia tidak terkecuali di Provinsi Kepulauan Riau. Jenis konfliknya pun sangat beragam seperti konflik yang berbasis politik, sosial, agama, etnik, radikal, antar aparat, sumber daya alam, sumber daya eko-nomi, rutin (tawuran, penghakiman massa, pengeroyokan) dan lainnya. Kondisi seperti ini jika dibiarkan dan tidak ada antisipasi sejak dini dikhawatirkan dapat menyulut konflik sosial dan faham radikalisme.

Di samping itu penyelesaian konflik sosial dan paham-paham radikal yang selama ini terjadi hanya sebatas penghentian kekerasan (seringkali peran pemerintah hanya sebagai pemadam kebakaran) atau baru damai negative belum mengarah pada damai positif atau substansial serta baru sebatas pencegahan represif. Ini karena persoalan dasar penyebab konflik sosial dan radikalisme di masyarakat belum diselesaikan secara mendasar misalnya persoalan marginalisasi kelompok masyarakat, segregasi antar kelompok, persoalan mayoritas minoritas, persoalan penduduk asli dan pendatang, hancurnya ruang-ruang budaya, akses ekonomi, pendidikan dan, lapangan pekerjaan, pertanahan, kemiskinan, agama dan kepercayaan dan lain-lain.

Dari gambaran di atas, penelitian ini hendak mengambil fokus tentang pemetaaan konflik dan radikalisme yang terjadi di Batam dengan metode kualitatif. Penelitian ini penting karena Batam beragamnya suku, ras, agama dan golongan sehingga daerah tersebut rentak terkadap konflik. 


\section{KONFLIK DAN RADIKALISME 1. Konflik}

Konflik merupakan sesuatu yang tidak bisa terhindarkan dalam kehidupan manusia. Konflik oleh beberapa aktor dijadikan sebagai salah satu cara yang dapat digunakan untuk mencapai keinginan atau tujuan. Menurut beberapa ahli konflik diartikan sebagai satu bentuk upaya untuk menampakkan, untuk mengidentifikasi, dan menjelaskan bahwa diantara setidaknya dua belah pihak memiliki perbedaan atau pertentangan. Perbedaan atau pertentangan dapat berwujud dalam bentuk perbedaan tujuan, kepentingan, nilai-nilai, budaya, suku, kelompok, ras dan agama. Menurut Webster dalam Pruitt dan Rubin, istilah "conflict" di dalam istilah aslinya berarti suatu "perkelahian, peperangan atau perjuangan". Kemudian menurut Pruitt dan Rubin, kata tersebut berkembang dengan masuknya "ketidak-sepakatan yang tajam atau oposisi atas berbagai kepentingan, ide dan lain-lain". ${ }^{3}$

Ada beberapa pengertian konflik menurut ahli sebagaimana dikutip dari Laporan Pengkajian Hukum tentang Mekanisme Penanganan Konflik Sosial. ${ }^{4}$ Menurut Taquiri (1977), konflik merupakan warisan kehidupan berlaku dalam berbagai keadaan akibat daripada keadaan ketidak setujuan, kontroversi dan pertentangan di antara dua pihak atau lebih pihak secara berterusan. Sedangkan menurut Robbin (1996), keberadaan konflik dalam organisasi ditentukan oleh persepsi

${ }^{3}$ Dean G. Pruitt and Jefrey Z. Rubin, 'Teori Konflik Sosial.-: Pustaka Pelajar', 2004, p. 9.

${ }^{4}$ Ahmad Ubbe, Laporan Pengkajian Hukum Tentang Mekanisme Penanganan Konflik Sosial (Pusat Penelitian dan Pengembangan Sistem Hukum Nasional, Badan Pembinaan ..., 2011). individu atau kelompok. Jika mereka tidak menyadari adanya konflik didalam organisasi maka secara umum konflik tersebut memper-sepsikan dianggap tidak ada. Sebaliknya, bahwa di dalam organisasi ada jika mereka konflik maka konflik tersebut telah menjadi kenyataan.

Pendapat Susan menyebutkan, konflik terdiri dari dua jenis. ${ }^{5}$ Pertama dimensi vertikal atau "konflik atas" yang dimaksud adalah konflik antara elite dan massa (rakyat). Elite disini bisa para pengambil kebijakan di tingkat pusat, kelompok bisnis atau para aparat militer. Kedua konflik horizontal, yakni konflik yang terjadi dikalangan massa (rakyat) sendiri.

Sedangkan tipe konflik juga terdiri dari dua yaitu konflik laten dan konflik manifest (nyata atau terbuka). Konflik laten adalah suatu keadaan yang didalamnya terdapat banyak persoalan, sifatnya tersembunyi dan perlu diangkat kepermukaan agar bisa ditangani. Sedangkan konflik manifest adalah situasi ketika konflik sosial telah muncul ke permukaan yang berakar sangat dalam dan sangat nyata, dan memerlukan berbagai tindakan untuk mengatasi akar penyebab dan berbagai efeknya.

Menurut Ranjabar, macam konflik dapat dibedakan ke dalam berbagai klasifikasi yang relevan berikut ini. ${ }^{6}$

a. Konflik menurut bubungannya dengan tujuan organisasi.

Ada dua bentuk konflik seperti ini, yakni (1) konflik fungsional. Konflik fungsional adalah konflik yang mendukungan tercapainya tujuan organisasi dan karenanya sering kali bersifat konstruktif. Konflik fungsi-

\footnotetext{
5 Novri Susan, Pengantar Sosiologi Konflik (Kencana, 2014), p. 99.

${ }^{6}$ Ranjabar Jacobus, 'Sistem Sosial Budaya Indonesia', Bandung: Alfabeta, 2013.
} 
onal sangat dibutuhkan organisasi; (2) Konflik disfungsional. Konflik dis-fungsional adalah konflik yang meng-hambat tercapainya tujuan organisasi dan karenanya seringkali bersifat destruktif (merusak).

\section{b. Konflik menurut bubungannya dengan posisi pelaku yang berkonflik.}

Ada tiga bentuk konflik dalam katehori ini, yaitu (1) konflik vertikal. Konflik vertikal adalah konflik antar tingkatan kelas antar tingkat kelom-pok; (2) Konflik horizontal. Konflik ini terjadi antara individu atau kelompok yang sekelas atau sederajat; (3) Konflik diagonal adalah konflik yang terjadi karena adanya ketidak adilan alokasi sumber daya ke seluruh organisasi yang menimbulkan perten-tangan secara ekstrim dari bagian yang membutuhkan sumber daya tersebut.

\section{c. Konflik menurut bubungannya dengan} sifat pelaku yang berkonflik.

Dalam kategori ini terdapat dua jenis, yakni (1) konflik terbuka adalah konflik yang diketahui oleh semua pihak yang adal dalam organisasi atau konflik yang diketahui masyarakat dalam suatu negara dan (2) konflik tertutup adalh konflik yang hanya diketahui oleh pihak yang terlibat saja, sehingga pihak yang ada di luar tidak tahu jika terjadi konflik.

\section{d. Konflik menurut bubungannya dengan waktu. \\ Untuk jenis ini terdapat dua} model, yakni (1) konflik sesaat. Konflik ini disebut juga dengan konflik spontan di mana terjadinya konflik ini hanya sesaat atau sementara. Umumnya, pemicunya karena kesalah pahaman yang tidak begitu berarti dan begitu pihak yang berkonflik diberi atau memberi penjelasan, maka konflik langsung berakhir; (2) Konflik berkelanjutan adalah suatu konflik yang berlangsung sangat lama dan sangat sulit untuk diselesaikan, di mana penyelesaian konflik tersebut masih harus melalui berbagai tahapan yang sangat rumit. Meskipun konflik telah selesai, tetapi di kemudian hari tidak menutup kemungkinan muncul-nya konflik baru yang merupakan kelanjutan dari konflik terdahulu.

\section{e. Konflik menurut bubungannya dengan pengendalian}

Konflik dalam ketegori ini terdiri dua, yakni (1) Konflik terkendali adalah suatu konflik di mana para pihak yang terlibat dengan konflik dapat dengan mudah mengendalikan konflik dan konflik selesai atau tidak meluas dan (2) Konflik tidak terkendali adalah suatu konflik dimana para pihak yang terlibat dengan konflik tidak dapat dengan mudah mengendalikan konflik dan konflik tidak selesai dan malahan semakin meluas.

\section{f. Konflik menurut hubungannya dengan} sistematika konflik.

Ada dua jenis model konflik, yaitu (1) Konflik nonsistematis adalah konflik yang bersifat acak, di mana terjadinya dengan spontanitas dan tidak ada yang mengomando dan tidak ada tujuan tertentu yang ditargetkan. Dalam konflik ini, pihak yang berkonflik tidak melakukan analisis kekuatan, kelemahan, peluang dan ancaman. Konflik ini disebut juga dengan konflik acak; dan (2) Konflik sistematis adalah konflik yang 
bersifat sistematis, dimana terjadinya telah direncanakan dan di program secara ada yang mengomando serta mem-punyai tujuan sistematis dan tertentu yang ditargetkan. Dalam analisis kekuatan, konflik ini, pihak yang berkonflik melakukan kelemahan, peluang dan ancaman. Setiap sikap dan perilaku dari satu pihak senantiasa dianalisis secara cermat dan hati-hati tentang berbagai respon yang diambil sehingga akan diperoleh keuntungan. Dalam konflik ini, analisis kekuatan, kelemahan, peluang dan ancaman diperhitungkan cermat, hati-hati dan sistematis.

g. Konflik menurut bubungannya dengan konsentrasi aktivitas manusia di dalam masyarakat.

Terdapat beragam jenis konflik dalam kategori ini sebagai berikut.

1. Konflik ekonomi adalah konflik yang disebabkan karena adanya perebutan sumber daya ekonomi dari pihak yang berkonflik.

2. Konflik politik adalah konflik yang dipicu oleh adanya kepentingan politik dari pihak yang berkonflik.

3. Konflik sosial adalah konflik yang disebabkan oleh adanya perbedaan kepentingan sosial dari pihak yang berkonflik.

4. Konflik budaya adalah konflik yang disebabkan oleh adanya perbedaan kepentingan budaya dari pihak yang berkonflik.

5. Konflik pertahanan adalah konflik yang dipicu oleh adanya perebutan hegemoni dari pihak yang berkonflik.

6. Konflik antar agama adalah konflik yang dipicu oleh adanya sentimen agama, perang salib merupakan contoh dari jenis agama. Salah satu dari sekian banyak konflik menurut Castro konflik antar dan Nielsen (2003) adalah konflik yang bersumber dari permasalahan sumber daya alam. Di era desentralisasi serta keber-adaan konflik yang mengedepan-kan globalisasi, demokratisasi, urbanisasi ternyata membawa dampak terhadap sosial sumber daya alam. Sehingga tidak salah bila di dalam undang-undang Pasal 5 Huruf D menerangkan bahwa salah satu sumber konflik sosial dan E yang di Indonesia sengketa sumber masyarakat dengan daya alam antar masyarakat dan/atau antar pelaku usaha atau distribusi sumber daya alam yang tidak seimbang dalam masyarakat.

Menurut Nasikun, sebagaimana dikutip oleh Ranjabar, ada beberapa indikator yang bisa dipergunakan untuk menilai intensitas daripada konflik yang terjadi di Indonesia. ${ }^{7}$ Pertama, demonstrasi. Yang dimaksud dengan demontrasi disini adalah sejumlah orang yang tidak menggunakan kekerasan mengorganisir diri untuk melakukan protes terhadap suatu rezim pemerintah atau pimpinan dari rezim pemerintah tersebut suatu tindakan atau suatu tindakan yang sedang direncanakan rezim.

Kedua, kerusuhan. Kerusuhan pada dasarnya adalah sama dengan demontrasi. Ia hanya beda dari demontrasi oleh karena kerusuhan mengandung penggu-naan kekerasan fisik, yang biasanya diikuti dengan pengrusakan barang-barang, pemukulan oleh alat keamanan atas pelaku-pelaku kerusuhan, menggu-nakan alat-alat

\footnotetext{
${ }^{7}$ Jacobus.
} 
pengendalian kerusuhan oleh para petugas keamanan di satu pihak dan penggunaan berbagai macam senjata atau alat pemukulan oleh pelaku kerusuhan di lain pihak. Ciri lain yang membedakan kerusuhan dari demons-trasi dan armed attack yang akan dikemukakan oleh spontanitas sebagai akibat dari suatu inside dan perlakuan kelompok yang kacau.

Ketiga, Serangan bersenjata (armed attack), yaitu suatu tindakan kekerasan yang dilakukan oleh atau untuk kepentingan suatu kelompok tertentu dengan maksud untuk melemah atau bahkan menghancurkan kekuasaan dari kelompok lain. Ia ditandai oleh terjadinya pertumpahan darah, pergulatan fisik atau perusakan barangbarang. Serangan bersenjata meliputi antara lain kekerasan politik yang terorganisir di dalam suatu sitem politik dan harus dibedakan dalam semua protes yang dilakukan tanpa menggunakan kekerasan (demonstrasi), dan insiden yang terjadi di dalam kerusuhan serta semua bentuk kekerasan di dalam rangka kejahatan kriminal yang tidak secara langsung ada hubungannya dengan penggolongan, konflik dan isu di dalam suatu proses politik.

Sedangkan dampak juga cukup banyak kategorinya. Secara umum, konflik sejatinya menghasilkan dua dampak yaitu dampak positif dan negatif. Konflik akan menghasilkan dampak negatif jika konflik itu dibiarkan, tidak dikelola serta telah mengarah pada tindakan destruktif. Sebaliknya, konflik akan berdampak positif jika konflik itu dapat dikelola sehingga konflik kemudian bersifat konstruktif.

Hal tersebut sejalan dengan pendapat Coser yang dikutip Sussan, konflik tidaklah hanya menghasilkan dampak yang negatif tetapi konflik juga memiliki dampak positif. ${ }^{8}$ Hanya saja, menurut Coser fungsi positif akan diperoleh ketika konflik memang dikelola dan diekspresikan sewajarnya. Dengan demikian dapat disimpulkan bahwa dampak dari konflik sangat bergantung apakah konflik itu bersifat destruktif ataukah bersifat konstruktif. Carpenter dan Kennedy, sebagaimana dikutip Susan, mengatakan konflik yang destruktif senantiasa muncul dalam bentuk kehancuran disemua sisi, seperti kehancuran tata sosial dan fisik. ${ }^{9}$ Konflik destruktif menyertakan cara-cara kekerasan di dalamnya. Dampak dari konflik destruktif menurut penulis di antaranya: (1) korban luka, (2) korban jiwa, (3) kerusakan sarana dan prasarana sosial, (4) kerugian materil, (5) keretakan dan kehancuran hubungan sosial.

Carpenter dan Kennedy, sebagaimana dikutip Susan, melanjutkan bahwa konflik konstruktif akan muncul dalam bentuk peningkatan kerjasama atau kesepakatan yang menguntungkan seluruh pihak berkonflik. ${ }^{10}$ Adapun dampak positif dari konflik sosial menurut Coser diantaranya yaitu mampu menciptakan dan memperkuat identitas dan kohesi kelompok sosial, meningkatkan partisipasi setiap anggota terhadap pengorganisasian kelom-pok serta dapat menjadi alat bagi suatu kelompok untuk mempertahankan eksistensinya. ${ }^{11}$

\section{Radikalisme}

Radikalisasi sebagai sebuah fenomena perilaku ekstrem atas sebuah ideologi, pandangan ataupun nilai sejatinya bukan dominan terjadi pada satu kelompok tertentu. Sejarah membuktikan bahwa fenomena tersebut

\footnotetext{
${ }^{8}$ Susan, pp. $57-58$.

${ }^{9}$ Susan, p. 7.

${ }^{10}$ Susan, p. 7.

${ }^{11}$ Susan, pp. 55-56.
} 
terjadi pada beragam kelompok, baik yang bersifat politis atau pun religius. Di Amerika Serikat (AS), gerakan radikalisme dilakukan oleh kelompok politik supremasi kaum kulit putih atau ultra nasionalist seperti kasus Bom Oklahoma oleh Timothy McVeigh; di Sri Lanka, kelompok Macan Tamil lahir dari sebuah entitas politik nasionalis; di Spanyol, kelompok ETA (Euskadi Ta Askatasuna) merupakan manifestasi gerakan separatis Basque yang ingin memerdekakan diri; di Jepang, Aum Shinrikyo pimpinan Shoko Asahara merupakan kelompok religius sinkretisme (Kristen, intrepretasi Yoga, dan nilai-nilai Nostradamus); di Kamboja, kelompok Khmer Merah lahir dari sebuah paham ideologi komunisme; di Irlandia Utara, kelompok INLA (Irish National Liberation Army), IPLO (Irish People's Liberation Organization), dan IRA (Irish Republican Army) merupakan gerakan separatis berideologi Katolik; dan daftar kelompok-kelompok radikal ini masih panjang lagi.

Namun, fokus global terhadap isu terkait radikalisme kini banyak terpaku pada kelompok-kelompok berbasis Islam, terutama pasca serangan pada Gedung World Trade Center, New York, AS, pada 11 September 2001. Tak luput pula dalam konteks Indonesia, aksi gerakan radikalisasi juga sering kemudian menjadikan organisasi-organisasi Islam sebagian bahkan berafiliasi dengan jaringan internasional sebagai pelaku utamanya. Intrepretasi ekstrem dari nilainilai Islam serta latar sosial-politik lokal dan internasional dipandang menjadi ikhwal munculnya pandangan radikalisme yang lalu bermetamorfosa menjadi aksi nyata tindak kejahatan.

Harus disadari bahwa kajian terkait radikalisasi merupakan sebuah ranah multi disipliner yang telaahnya sangat multi dimensi. Ini yang kemudian membuat kajian ini seringkali kurang komprehensif karena hanya dibahas dari sudut pandang tertentu. Dan, melihat arus utama kajian ini yang sering muncul dari para ilmuan di bidang kajian Hubungan Internasional (Studi Kawasan, Kejahatan Trans National, Politik Kekerasan), maka perlu rasanya untuk dapat menjelaskan dari sudut pandang lain, terutama dari aspek komunikasi dan media, terutama dalam konteks Indonesia.

Istilah radikalisasi menjadi istilah penting yang selalu muncul ketika membicarakan ranah terorisme. Namun konsep ini sejatinya kabur dan tidak terdefinisikan secara solid. Sebagai contoh, seperti dikemukakan oleh Rahimullah dkk (2013), ${ }^{12}$ NATO atau pun kamus istilah militer pada Kementerian Pertahanan AS, tak pernah kemudian menyediakan definisi jelas tentang istilah radikal. Di level akademisi pun, istilah radikalisasi memiliki beragam manifestasi definisi. Porta dan LaFree mengutip banyak sekali definisi terkait radikalisasi. ${ }^{13}$ Bebepera di antara-nya;

a) Radikalisasi harus dipahami sebagai sebuah proses yang dapat mengarah pada peningkatan penggunaan kekerasan politik;

b) sebuah proses eskalasi yang mengarah ke kekerasan;

c) Sebuah proses yang ditandai dengan peningkatan komitmen dan penggunaan sarana dan strategi kekerasan dalam konflik politik;

d) Sebuah proses interaksi antara kelompok-kelompok kekerasan

12 Riyad Hosain Rahimullah, Stephen Larmar, and Mohamad Abdalla, 'Radicalization and Terrorism: Research within the Australian Context', International Journal of Criminology and Sociology, 2 (2013), 180-85.

13 Donatella Della Porta and Gary LaFree, 'Guest Editorial: Processes of Radicalization and de-Radicalization', International Journal of Conflict and Violence (IJCV), 6.1 (2012), 4-10. 
dengan lingkungan mereka, atau efek interaksi mutual di antara para aktor yang penuh kebencian.

e) Secara fungsi, radikalisasi politik adalah peningkatan persiapan untuk dan komitmen melakukan konflik antar grup.

Dapat dideskripsikan, radikalisasi adalah perubahan keyakinan, perasaan, dan perilaku yang sejalan dengan justifikasi kekerasan oleh kelompok dan menuntut adanya pengorbanan untuk membela kelompok, Penggunaan strategi kekuatan fisik untuk memengaruhi audiens.

Untuk dapat lebih memahami konsep radikalisasi yang beragam ini, Schmid menyarankan agar melihat akar katanya-radikalisme dan dinamika maknanya secara aspek historis. ${ }^{14}$ Pada abad ke-19, banyak partai politik menyebut diri mereka sebagai "radikal" dalam arti menjadi penggiat advokasi paham republikanisme untuk melawan royalisme (monarki). Kaum radikal ini menuntut sistem demokrasi yang hak memilihnya tidak terikat status kekayaan atau gender. Mereka juga bukanlah kelompok yang bersifat revolusioner, namun lebih bersifat reformis. Bahkan, pada paruh pertama abad ke-19 di Inggris, kaum "radikal" ini hampir sama dihormatinya dengan kaum liberal. Banyak dari mereka, pada akhir abad ke-19 dan abad ke-20 justru adalah aktivis anti-kekerasan. Perjuangan mereka menuntut hak memilih bagi kaum wanita bisa jadi ilegal, namun bukan sesuatu hal yang tidak terlegitimasi. Menariknya, beberapa tuntutan kaum radikal abad 19 ini menjadi hal-hal arus utama penting sekarang ini. ${ }^{15}$

Berdasarkan paparan di atas, konsep radikalisme mengalami pergeseran

14 Alex P. Schmid, 'Radicalisation, deRadicalisation, Counter-Radicalisation: A Conceptual Discussion and Literature Review', ICCT Research Paper, 97.1 (2013), 22.

${ }^{15}$ Schmid, p. 7. makna yang sangat hanya dalam waktu sekitar satu abad saja. Radikal pada abad ke-19 berkonotasi positif dengan merujuk pada liberal, pro-demokrasi, progresif. Sebaliknya, radikal sekarang ini (terutama dikaitkan dengan Islam) cenderung bermakna sebaliknya. Mereka diidentikkan anti liberal, fundamentalis, anti demokrasi, serta penuh dengan agenda kekerasan.

Berangkat dari hal ini, jelas terlihat bahwa „radikale adalah konsep relatif, dan tentu saja akan memengaruhi makna turunan katanya seperti „radikalisasi." Oleh karena itu, Schmid pun lebih memilih sebuah konsep/definisi radikal yang lebih dapat mengakomodasinya dalam relasi aktivitas politik arus utama dalam konteks masa demokratis kini. Schmid menegaskan bahwa konsep radikalisme dapat dideskripsikan dalam dua elemen penting yang dapat merefleksikan pikiran/sikap dan aksi/perilaku

1. Mengadvokasi perubahan politik berdasarkan sebuah tudingan bahwa keberadaan entitas status quo tidak dapat diterima, dan bersamaan dengan itu sebuah alternatif muncul pada kaum radikal.

2. Sarana advokasi untuk menghasilkan solusi dan transformasi radikal sistem bagi pemerintah ataupun masyarakat bisa melalui cara non-kekerasan dan demokratis (lewat persuasi dan reformasi) atau kekerasan dan nondemokratis.

\section{POTENSI DAN PETA RAWAN KONFLIK DAN RADIKALISME DI BATAM}

Pemetaan radikalisme pada pemaparan penelitian ini akan memberikan suatu gambaran dan kondisi secara real dilapangan dan keadaan yang sesungguhnya terjadi di Provinsi Kepulauan Riau, khususnya di Kota 
Batam. Untuk memudahkan, maka diuraikan menjadi bagian-bagian sebagai berikut.

\section{Pristiwa konflik / radikalisme}

Akhir-akhir ini pemahaman radikalisme sering dikaitkan keberadaan agama (khususnya islam), kondisi ini dapat dimaklumi karena dari ajaran agama para generasi muda/remaja mendapatkan doktrin dan pemahaman yang mendasar tentang akan arti kehidupan ini, inilah yang berbahaya jika pemberian pemahaman agama yang keliru dan sempit serta fanatis, sehingga sering kali ajaran agama yang sedemikian rupa akan memberikan perubahan yang mendasar pada pemikiran generasi muda/remaja sehigga muncullah pemahaman bahwa agamanya dan ajarannyalah yang paling benar, sedangkan agama dan ajaran diluar mereka adalah salah dan perlu diperanggi (radikalisme agama yang keliru). Dari pemikiran seperti inilah akan muncul aksi kekerasan, pemaksaan, jihad dan bahkan teror pada kelompok atau agama lain oleh kelompok agama tertentu.

Untuk daerah di lokasi penelitian di Kota Batam, secara umum dapat ditarik kesimpulan dari kondisi dilapangan bahwa tidak ada peristiwa atau konflik/radikalisme yang sangat menonjol terjadi, beberapa peristiwa baik itu kekerasan/konflik tidak dilakukan secara radikal yang dilatar belakanggi agama (hanya ada beberapa permasalahan dan konflik antar agama dan antar umat beragama tetapi tidak sampai menimbulkan ancaman dan teror). Perlu di ketaui tidak ada satu agamapun yang mengajarkan permusuhan dan perkelahian, semua agama mengajarkan kebenaran dan kerukunan sebagai suatu rahmat. Dalam pemahaman agama islam konsep Kerukunan dikenal dengan istilah "tasamub" atau toleransi. Sehingga yang di maksud dengan toleransi ialah kerukunan sosial kemasya-rakatan, bukan dalam bidang aqidah Islamiyah (keimanan), karena aqidah telah digariskan secara jelas dan tegas di dalam Al-Qur'an dan AlHadits.

Dalam bidang aqidah atau keimanan seorang muslim hendaknya meyakini bahwa Islam adalah satu-satunya agama dan keyakinan yang dianutnya sesuai dengan firman Allah SWT. dalam Surat Al Kafirun (109) ayat 1-6 sebagai berikut: Artinya: "Katakanlah, "Hai orang-orang kafir!". Aku tida menyembah apa yang kamu sembah. Dan tiada (pula) kamu menyembah Tuban yang aku sembah. Dan aku bukan penyembah apa yang biasa kamu sembah dan kamu bukanlah penyembah Tuban yang aku sembah. Bagimu agamamu dan bagiku agamaku". "Janganlah kamu memaki sembahan-sembahan yang mereka sembah selain Allah, karena mereka nanti akan memaki Allah dengan melampaui batas tanpa pengetahuan...." (QS. VI: 108).

Rasulullah SAW bersabda: "Barangsiapa mengganggu kaum dzimmi (non-Muslim), maka ia telah mengganggu aku" (Al-Hadits) Al-Qur'an Surat AlA'nam ayat 108 yang berbunyi: “ Dan janganlan kamu memaki sembahansembahan yang mereka sembah selain Allah, karena mereka nanti akan memaki Allah dengan melapaui batas tanpa pengetahuan. Demikianlah kami jadikan setiap umat menganggap baik peker-jaan mereka. Kemudian Tuhan merekalah kembali mereka, lalu Dia memberitahukan kepada mereka apa yang dahulu mereka kerjakan".

Dalam sejarah kehidupan Rasulullah SAW, kerukunan sosial kemasyarakatan telah ditampakkan pada masyarakat Madinah. Pada saat itu rasul dan kaum muslim hidup berdampingan dengan masyarakat Madinah yang berbeda agama (Yahudi dan Nasrani).

Dalam ajaran agama kristen konsep kerukunan adalah (1) Tuhan itu baik kepada semua orang (Mazmur 145:9) dan 
(2) Barang siapa tidak mencintai, ia tidak menyembah Allah (1 Yoh 4:8)

Jadi tindakan dasar bagi setiap teori atau praktek yang mengadakan perbedaan mengenai manusia serta hak-hak yang bersumber padanya antar manusia dan manusia. Gereja mengecam setiap diskriminasi. Gereja juga mengecam penganiayaan berlandaskan warna kulit, status sosial, ajaran yang berbeda.

I Petrus 2 ayat 12 Milikilah cara hidup yang baik di tempat-tempat bangsa bukan Yahudi supaya apabila mereka memfitnah kamu sebagai orang durjana mereka dapat melihatnya dari perbuatanperbuatanmu yang baik dan memuliakan Allah pada hari Ia melawat mereka. Dalam Pandangan Iman Kristen Kerukunan dan toleransi antar umat beragama adalah penting yang dapat terwujud (1) Praktek hidup beragama secara benar dan efektif, (2) Tercapainya tujuan dari agama yakni, terwujudnya keselamatan, kebahagiaan di dunia dan akhirat yang dapat dicapai melalui cinta kasih, dan (3) Terwujudnya kebutuhan yang hakiki dan cita-cita setiap insan meanusia yaitu: damai sejahtera lahir dan batin dalam dunia yang harmonis, rukun dan damai.

Dalam ajaran agama katolik tentang kerukunan, sejak Konsili Vatikan II, Gereja Katolik sangat menekankan dan turut memperjuangkan kerukunan dan toleransi antar umat beragama, karena dan demi keharmonisan, persaudaraan, damai sejahtera, persatuan, dan "keselamatan" segenap umat manusia. Kerukunan dan toleransi antar umat beragama dilihat sebagai suatu kebutuhan hakiki dan universal. Dikatakan oleh Konsili Vatikan II : Tetapi kita tidak dapat menyerukan nama Allah Bapa semua orang, bila terhadap orang-orang tertentu, yang diciptakan menurut citra-kesamaan Allah, kita tidak mau bersikap sebagai saudara. Hubungan manusia dengan Allah Bapa dan hubungan-nya dengan sesama manusia saudaranya begitu erat, sehingga Allah berkata : "Barang siapa tidak mencintai, ia tidak mengenal Allah" (1 Yoh 4:8). Jadi tiadalah dasar bagi setiap teori atau praktek, yang mengadakan pembedaan mengenai martabat manusia serta hak-hak yang bersumber padanya antara manusia dengan manusia, antara bangsa dengan bangsa.

Maka Gereja mengecam setiap diskriminasi antara orang-orang atau penganiayaan berdasarkan keturunan atau warna kulit, kondisi hidup atau agama, sebagai berlawanan dengan semangat Kristus. Oleh karena itu Konsili suci, mengikuti jejak para Rasul kudus Petrus dan Paulus, meminta dengan sangat kepada Umat beriman kristiani, supaya bila ini mungkin "memelihara cara bidup yang baik di antara bangsa-bangsa bukan Yabudi" (1Ptr 2:12), dan "mereka bidup dalam damai dengan semua orang, sehingga mereka sunggub-sungguh menjadi putera Bapa di surga." ${ }^{16}$ Dalam pandangan Gereja Katolik, kerukunan dan toleransi antar umat beragama adalah penting bagi Praktek hidup beragama secara benar, konsekwen dan efektif. Tercapainya tujuan dari agama, yakni terwujudnya keselamatan/kebahagiaan di dunia maupun di akhirat, yang dapat dicapai melalui cinta kasih, yang tidak lain adalah intimitas relasi antara manusia dengan Allah dalam intimitas relasi antara manusia dengan manusia, terwujudnya kebutuhan yang hakiki dan cita-cita setiap insan manusia, yaitu damai sejahtera lahir dan batin dalam "dunia" yang harmonis, rukun dan damai.

Dalam ajaran agama buddha tentang kerukunan. Raja Asoka dalam menjalankan pemerintahannya benar-benar menjaga toleransi dan kerukunan hidup beragama, semua agama yang berkembang saat itu diperlakukan adil. Untuk mewujudkan kerukunan hidup beragama tersebut, Raja

16 Robert Hardawiryana, 'Dokumen Konsili Vatikan II', Jakarta: Obor, 1993, pp. 314-15. 
Asoka telah mencanangkan Kerukunan Hidup Beragama yang terkenal dengan "Prasasti Batu Kalinga No. XXII Raja Asoka".

Prasasti raja asoka."Janganlah kita hanya menghormati agama sendiri dan mencela agama orang lain tanpa suatu dasar yang kuat. Sebaliknya agama orang lain pun hendaknya dihormati atas dasardasar tertentu. Dengan berbuat demikian kita telah membantu agama kita sendiri, untuk berkembang di samping menguntungkan pula agama orang lain. Dengan berbuat sebaliknya kita telah merugikan agama kita sendiri, di samping merugikan agama orang lain. Oleh karena itu, barang siapa menghormati agamanya sendiri dan mencela agama orang lain, semata-mata karena didorong oleh rasa bakti pada agamanya sendiri dengan berpikir; bagaimana aku dapat memuliakan agamaku sendiri. Dengan berbuat demikian ia malah amat merugikan agamanya sendiri. Oleh karena itu, kerukunanlah yang dianjurkan dengan pengertian bahwa semua orang hendaknya mendengarkan dan bersedia mendengar ajaran orang lain".

Selain menjaga diri dengan Sila, umat Buddha dapat mengembangkan kesempur-naan-kesempurnaan (Paramita). Menurut Sang Buddha berkembangnya perpecahan dan hancurnya persatuan dan kesatuan (kerukunan) mengakibatkan pertentangan, pertengkaran. Sang Buddha bersabda dalam Dhammapada ayat 6, sebagai berikut:"Mereka tidak tahu bahwa dalam pertikaian mereka akan hancur dan musnah, tetapi mereka yang melihat dan menyadari hal ini damai dan tenang".

Sumber dari perpecahan menurut Sang Buddha dijelaskan dalam Dhamma pada ayat 5, yaitu, "Di dunia ini kebencian belum pernah berakhir jika dibalas dengan membenci, tetapi kebencian akan berakbir kalau dibalas dengan cinta kasih. Ini adalah bukum kekal abadi”. Ajaran agama hindu tentang kerukunan.

Tri hita karana. Secara harfiah Tri Hita Karana dapat diartikan tiga penyebab kebahagiaan. (tri artinya tiga, hita artinya kebahagiaan, dan karana artinya penyebab). Unsur-unsur Tri Hita Karana adalah :

a. Parhyangan, yaitu membina hubungan yang harmonis antara manusia dengan Tuhan Yang Maha Esa.

b. Pawongan, yaitu membina hubungan yang harmonis antara sesama manusia sehingga tercipta keselarasan, keserasian dan keseimbangan.

c. Palemahan, yaitu membina hubungan yang harmonis antara manusia dengan alam lingkungannya.

Tri kaya parisudha. Secara arti kata Tri Kaya Parisudha dapat diterjemahkan prilaku yang suci. (tri artinya tiga, kaya artinya prilaku, parisudha artinya semuanya suci). Unsur-unsur Tri Kaya Parisudha adalah Manacika Parisudha, yaitu berpikir yang suci, baik dan benar; Wacika Parisudha, yaitu berkata yang suci, baik dan benar; Kayika Parisudha, yaitu berbuat yang suci, baik dan benar.

Tat twam asi, apabila diterjemahkan secara artikulasi Tat Twam Asi berarti Itu adalah Kamu atau Kamu adalah Itu. Tat Twam Asi menjurus kepada Tepa Selira atau Tenggang Rasa yang dapat menuntun sikap dan prilaku manusia senantiasa tidak melaksanakan perbuatan yang dapat menimbulkan sakit hati sehingga terjadi perpecahan dan permusuhan.

Dalam ajaran Agama Khong $\mathrm{Hu} \mathrm{Cu}$ Tentang Kerukunan. Nabi Kongzi Bersabda: "Seorang Junzi/susilawan dapat rukun meski tidak dapat sama, seorang rendah budi dapat sama meski tidak dapat rukun". (Lunyu. XIII: 23) Kerukunan adalah dambaan setiap manusia, hal ini pulalah yang menjadi salah satu tujuan dari pengajaran agama, maka menjadi ironis jika dengan dalih untuk menegakkan ajaran 
agama justru malah merusak kerukunan itu sendiri. Kerukunan dapat tercipta bukan hanya dalam ruang yang serba sama, maka biarkanlah perbedaan itu hadir apa adanya.

Kongzi tidak pernah mengajarkan umatnya untuk mengungguli pihak manapun juga, tidak ada satu ayatpun dari kitab suci $\mathrm{Si}$ Shu yang memerintahkan umatnya untuk berlomba-lomba menambah pengikut, terlebih dengan cara merebut umat dari agama lain. Nabi Kongzi bersabda, "Bila berlainan jalan suci (agama) jangan berdebat". (Lunyu. XV: 40). "Orang yang mengaku dirinya baik sesungguhnya belum masuk hitungan sebagai orang baik".

Dari ajaran agama tentang kerukunan dapat dimaknai tidak ada satu ajaran agamapun yang mengajarkan permusuhan dan penghinaan, sekali lagi negara menjamin tiap-tiap penduduk untuk memeluk agamanya dan berbadat menurut agama dan kepercayaannya.

Dalam konteks negara sejak tujuh tahun era reformasi Indonesia (1998 2006) telah lahir kebijakan nasional yang mendasar dan konstruktif dalam pembangunan dan jaminan kebebasan beragama. Perubahan UUD 1945 dalam 4 tahap (1999-2002) yang menyangkut hak keagamaan warga negara dan beberapa legislasi hukum nasional yang berkaitan dengan masalah keagamaan banyak dipengaruhi oleh prinsip Hak Asasi Manusia (HAM). Kondisi ini bisa dilihat dari tiga regulasi dasar :

UU No. 9 Tahun 1999 tentang HAM yang menegaskan kembali kemerdekaan memeluk dan menjalankan agama dan kepercayaan. UU No. 26 Tahun 2000 tentang Pengadilan HAM yang memasukan kejahatan kemanusiaan yang dilakukan secara luas dan sistematis kepada sebuah kelompok atau asosiasi yang salah satunya berdasarkan identitas agama tertentu bisa digolongkan sebagai pelanggaran HAM berat ; dan Perubahan kedua UUD 45 (tahun 2000) yang menegaskan kembali kebebasan untuk memeluk dan beribadah sesuai agama dan kepercayaan (pasal $28 \mathrm{E}$ ayat 1 dan pasal 28 I ayat 1). Kemudian tahun 2006 lahir peraturan bersama antara menteri dalam negeri dan menteri agama dalam hal kerukunan, terutama yang mengatur pendirian rumah ibadah untuk meujudkan kerukunan antar umat beragama.

Provinsi Kepulauan Riau memiliki jumlah penduduk berdasarkan agama sebanyak 2.159.035 orang (Islam 1.670.271, Kristen 266.832, Katolik 53.555, Hindu 1.869, Budha 162.556, Konghuchu 3.552 lainnya 400), dari jumlah tersebut 1.249.702 orang atau sekitar 57,9 persen penduduk berada di Kota Batam. Dari jumlah penduduk tersebut Provinsi Kepulauan Riau memiliki 6.048 rumah ibadah.

\section{Organisasi dan gerakan sosial}

Secara umum gerakal radikalisme agama yang terjadi di Batam, masih di gerakkan oleh organisasi dari kelompok mereka sendiri, sulit untuk membuktikan (perlu penelitian secara seksama), Pada waktu penelitian dilakukan tidak ada pergerakan (organisasi mereka) yang secara aktif melaksanakan aktifitas atau gerakan penyebaran agama (kondisi ini diperkuat dengan wawancara dari tokoh masyarakat dan tokoh agama serta informasi dari pihak kementrian agama).

Kelompok mereka juga menyadari bahwa konflik antar umat beragama tidak akan menyelesaikan masalah, akan tetapi beberapa diantra mereka juga akan rela berbuat apa saja demi agama yang dinyakininya, di sinilah pentingnya keberadaan pemerintah dan organisasi keagamaan (MUI dan ormas agama) dalam membina mereka kearah jalan yang benar. Kondisi ini jangan dianggap sebelah mata, di daerah Batam ketenagan dan kedamaian akan berimplikasi luas untuk 
Kepulauan Riau secara Umum. Sehingga kerukunan umat beragama merupakan barometer dari kerukunan di Kepulauan Riau.

Para tokoh agama merupakan ujung tombak dalam memberikan pemahaman kepada masyarakat. Mereka harus berperan bersama-sama mencegah aksi-aksi faham radikalisme. Agama bukanlah untuk memisahkan seseorang dengan orang lain, agama bertujuan untuk menyatukan mereka. Adalah suatu malapetaka bahwa saat ini agama telah sedemikian terdistorsi sehingga menjadi penyebab perselisihan dan pembantaian. Semua agama mengklaim atau diklaim oleh umatnya sebagai agama universal, dan memang ajaran yang sifatnya universal terdapat pada semua agama, semua agama mengajarkan kebaikan dan saling menghormati terhadap pemeluk agama lain. K. H. A. Hasyim Muzadi menyatakan, apa-apa yang sama dalam masing-masing agama jangan dibedabedakan dan apa yang berbeda-beda dalam agama masing-masing jangan disamasamakan.

Secara umum dari penelitian bebera tokoh agama dan tokoh masyarakat yang tergabung dalam organisasi keagamaa (MUI, FKUB, FKDM, FPK) serta organisasi kedaerahhan lainnya, pemerintah di Kota Batam maupun Provinsi telah banyak membantu menanggani permasalah konflik, terutama konflik radikalisme agama.

\section{Peta rawan kejadian}

Konflik dan berkembangnya paham radikalisme agama merupakan sebuah fenonema yang tidak dapat dihindari dalam sebuah kehidupan sosial dan kemasrakatan. Konflik memiliki dua dimensi pertama adalah dimensi penyelesaian dan dimenasi keduanya adalah bentuk. Hal yang disebut pertama memiliki dua ujung yakni terjadinya perpecahan dan tindak kekerasan (radikal) yang melahirkan disintegrasi, sementara pada ujung lainnya terjadi konsolidasi setelah perbedaan-perbedaan dapat dikemukakan solusinya. Oleh karena itu, konflik perlu diantisipasi sedemikian rupa agar ujung pertama yang dapat memicu terjadinya tindak kekerasan dan kerugian dapat dihindari. Konflik dapat berkembang dari paham-paham radikal yang berlebihan yang menganggap kelompok atau pahamnya yang paling benar serta utama.

Secara umum kota Batam Provinsi Kepulauan Riau dapat dikatakan tidak memiliki titik-titik potensi radikalisme secara ekstrim akan tetapi dari hasil FGD dapat ditarik kesimpulan bahwa sebagian besar bayak terjadi hanya sebatas konflik dan beberapa diantaranya juga ada konflik terbuka. Potensi-potensi tersebut antara lain adalah konflik agama, pertanahan, konflik etnis dan konflik penguasaan atas sumber daya alam, dengan intensitas kejadian yang tidak begitu sering dan kentara (lihat gambar peta daerah rawan konflik)

Kota Batam merupakan suatu daerah atau kawasan dengan jumlah penduduk terbanyak di provinsi Kepulauan Riau, serta tingkat intensitas penduduk yang berimigrasi yang sangat tinggi, disamping itu juga Kota Batam merupakan kota industri yang mana setiap tahunnya masalah ketenaga kerjaan sering mengakibatkan konflik terbuka yang memerlukan penanganan ekstra baik itu masalah agama, upah, masalah ketenaga kerjaan, tempat tinggal dan lain-lain. Kondisi ini jika tidak ditanggani secara serius akan mengakibatkan dampak konflik yang lain yang lebih luas lagi. Untuk lebih memahami kondisi daerah rawan konflik sosial, berikut ini akan dapat dilihat pemetaan daerah raawan konflik sosial, radikalisme agama, di Kota Batam sebagai berikut. 


\section{PETA RAWAN KONFLIK SOSIAL DI KOTA BATAM \\ konflik ini dapat diatasi jika pihak-pihak yang terlibat mau berunding dan mencari}
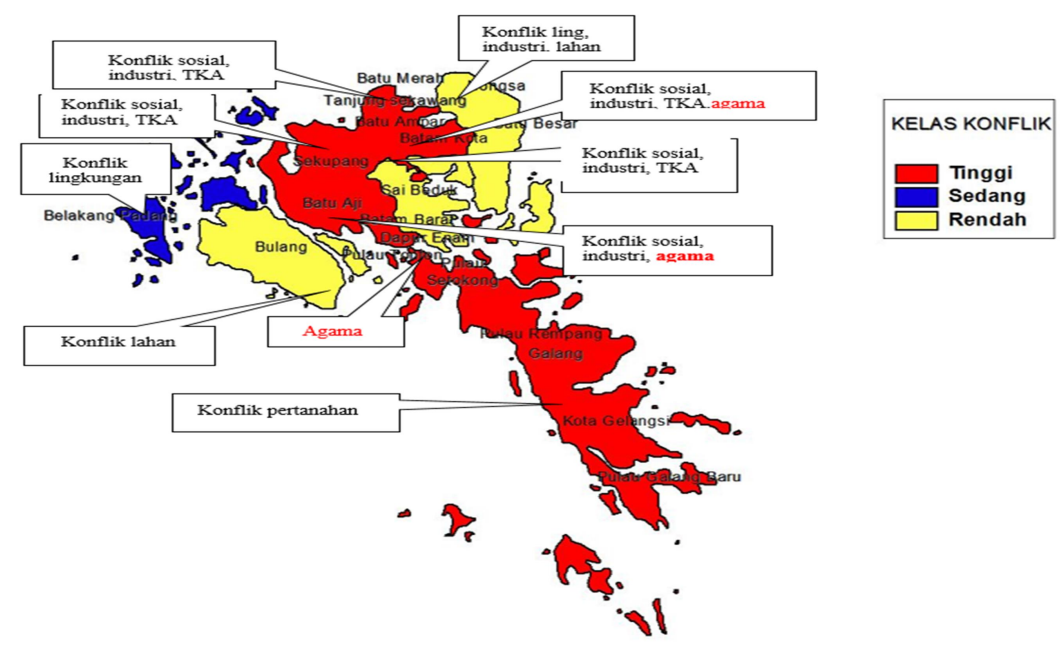

\section{KESIMPULAN}

Kota Batam, dari berbagai persoalan baik itu Konflik sengketa lahan, konflik industri, konflik agama dan lain-lain perlu disikapi secara arif dan bijaksana dan perhatian yang serius dari semua pihak dalam menyelesaikan konflik-konflik yang ada agar konflik tersebut tidak dimanfaatkan oleh pihak-pihak tertentu untuk memper-keruh keadaan, walaupun di sadari bahwa konflik-konflik di kota Batam penelitian tersebut belum menjurus kepada tindakan radikal akan tetapi hal ini tidak bisa dibiarkan begitu saja karena dari konflik ini tidak menutup kemungkinan akan meluas menjadi radikal dan, beberapa indikasi dari konflik tersebut ada yang mengunakan pihak-pihak tertentu (pihak ketiga) dimana pihak ketiga ini menghalalkan segala cara agar tujuan mereka tercapai baik mengunakan kekerasan maupun teror, seperti konflik penguasaan lahan dan konflik tenaga kerja serta konflik agama.

Untuk konflik industri dan sosial, dimana konflik ini hanya berupa aktifitas buruh setiap tahunnya dan berkaitaan dengan upah minimum serta masalahmasalah sosial di kehidupan masyarakat solusi dalam pemecahan masalah yang dihadapi, hal ini penting karena Koata Batam Kepulauan Riau berada di daerah perbatasan, hal ini tidak menutup kemungkinan upaya buruh utuk memperjuangkan haknya ditunggangi oleh kepentingan negara asing.

Untuk Konflik agama, konflik ini perlu keseriusan pemerintah dan pihak pihak tertentu untuk turut serta menyelesaikan setiap masalah yang ada, karena konflik ini berkaitan dengan aqidah dan iman seseorang, sehingga pihak-pihak yang terlibat sangup mempertaruhkan nyawa, harta dan benda demi keyakinan yang dianutnya. Khusus untuk kondisi Batam perlu keseriusan disamping masalah pendirian rumah ibadah yang menjadi perhatian, kasus agama sempalan yang berkembang juga menuntut perhatian yang seius (data terakhir agama semapalan yang berkembang menunjukkan aktifitas yang berkembang terus tidak hanya faham syiah tetapi paham-paham lain juga turut berkembang seperti Ahmadiah, Qiblatul Amin, Misykatul Anuar, Gapatar, Baha'i, Millah Abraham, Saksi Yahofa Dan Pengikut Parmalin (Mengaku Agama Kristen) walaupun perkembangan agama 
tersebut masih tidak menetap dan berpindah-pindah di beberapa daerah di Batam[]

\section{DAFTAR PUSTAKA}

Della Porta, Donatella, and Gary LaFree, 'Guest Editorial: Processes of Radicalization and deRadicalization', International Journal of Conflict and Violence (IJCV), 6.1 (2012), 4-10

Hardawiryana, Robert, 'Dokumen Konsili Vatikan II', Jakarta: Obor, 1993

Jacobus, Ranjabar, 'Sistem Sosial Budaya Indonesia', Bandung: Alfabeta, 2013

Kartasasmita, Ginandjar, Pembangunan Untuk Rakyat: Memadukan Pertumbuban Dan Pemerataan (Cides, 1996)

Pruitt, Dean G., and Jefrey Z. Rubin, 'Teori Konflik Sosial.-: Pustaka Pelajar', 2004

Rahimullah, Riyad Hosain, Stephen Larmar, and Mohamad Abdalla, 'Radicalization and Terrorism: Research within the Australian Context', International Journal of Criminology and Sociology, 2 (2013), 180-85

Schmid, Alex P., 'Radicalisation, deRadicalisation, CounterRadicalisation: A Conceptual Discussion and Literature Review', ICCT Research Paper, 97.1 (2013), 22

Soemarwoto, Otto, Ekologi, Lingkungan Hidup Dan Pembangunan Edisi Revisi (Jakarta: Penerbit Djambatan, 1997)

Susan, Novri, Pengantar Sosiologi Konflik (Kencana, 2014)

Ubbe, Ahmad, Laporan Pengkajian Hukum Tentang Mekanisme Penanganan Konflik Sosial (Pusat Penelitian dan Pengembangan Sistem Hukum
Nasional, Badan Pembinaan ..., 2011) 